\title{
Transcriptional control of Drosophila fushi tarazu zebra stripe expression
}

\author{
Charles R. Dearolf, ${ }^{1}$ Joanne Topol, ${ }^{1,2}$ and Carl S. Parker \\ Division of Chemistry and 2Division of Biology, California Institute of Technology, Pasadena, California 91125 USA
}

\begin{abstract}
The Drosophila segmentation gene fushi tarazu $(f t z)$ is expressed in a characteristic pattern of seven stripes during early embryogenesis. We have used $f t z-l a c Z$ fusion genes to determine the effects of deleting relatively small segments of the $\mathrm{ftz}$ promoter region necessary for this expression. We find that this regulatory region contains multiple activator and repressor elements. The deletion of one particular activator element results in a preferential loss of expression in the posterior stripes, whereas the deletion of other activator elements causes a general reduction in expression throughout the germ band. The removal of repressor elements results in a loss of repression in the odd-numbered parasegments. We also find that the $f t z$ upstream enhancer element functions primarily in epidermal cells. Our results indicate that $f t z$ transcription is activated in each parasegment through the 'zebra stripe' promoter region and is then inhibited selectively in the odd-numbered parasegments by repressors that bind directly to elements within this promoter region.
\end{abstract}

[Key Words: Drosophila fushi tarazu gene; segmentation; transcriptional control]

Received November 9, 1988; revised version accepted January 4, 1989.

Segmentation in Drosophila melanogaster is controlled by a network of interacting genes (for review, see Akam 1987; Nüsslein-Volhard et al. 1987; Scott and Carroll 1987; Ingham 1988) of which fushi tarazu (ftz) is one of the best studied. $f t z$ is necessary for the development of the even-numbered parasegments (Wakimoto et al. 1984) and for the correct expression of homeotic and other segmentation genes (Duncan 1986; Howard and Ingham 1986; Ingham and Martinez-Arias 1986). Embryos in which the $f t z$ product is either lacking (Wakimoto et al. 1984) or indiscriminately expressed (Struhl 1985) develop pair-rule phenotypes, whereby every other parasegment is abnormal.

$f t z$ transcripts and proteins are expressed in a highly regulated manner during embryogenesis (Hafen et al. 1984; Kuroiwa et al. 1984; Weiner et al. 1984; Weir and Kornberg 1985; Carroll and Scott 1985; Carroll et al. 1988a; Doe et al. 1988; Krause et al. 1988). ftz transcripts are first detected throughout the embryo after the ninth nuclear division. They are distributed uniformly around the periphery of the embryo from $\sim 15 \%$ to $65 \%$ egg length after the eleventh nuclear division but resolve into seven discrete stripes by the formation of the cellular blastoderm. $f t z$ proteins are detected in cells of the presumptive even-numbered parasegments at this stage and are present until the germ band is fully elongated. $f t z$ is also expressed later in neural cells and in the hindgut.

The exact mechanism by which the $f t z$ 'zebra stripe' expression pattern is generated is not yet known. One

'The first two authors made equivalent contributions to this manuscript. approach to studying this problem is to examine the effects on $\mathrm{ftz}$ expression of mutations in other segmentation genes /Carroll and Scott 1986; Howard and Ingham 1986; Carroll et al. 1986, 1988b; Harding et al. 1986; Frasch and Levine 1987). These experiments indicate that the product of the hairy $(h)$ gene acts in some way to repress $f t z$ expression, a result confirmed by in vivo overproduction of the $h$ protein (Ish-Horowicz and Pinchin 1987). Mutations in other segmentation genes also disrupt $f t z$ expression; but the reasons for these disruptions generally are not so clear, because the altered $\mathrm{ftz}$ patterns could, in some cases, be due to indirect effects of the mutations. The numerous other early-acting genes, which do not cause 'segmentation'-type phenotypes when mutated, will not be examined by this approach in most cases, although it is likely that some directly regulate the transcription of segmentation and homeotic genes (Biggin and Tjian 1988).

A complementary approach is to determine the biochemical and molecular components through which $\mathrm{ftz}$ is regulated transcriptionally. This approach is especially relevant for the $f t z$ gene, because the observed pattern of $f t z$ expression is controlled, to a large extent, at the level of transcription (Edgar et al. 1987). The first studies of this type have shown that the ftz locus contains a complex promoter (Hiromi et al. 1985; Hiromi and Gehring 1987). Sequences necessary for the correct stripe pattern are located between -669 and +73 bp from the start point of transcription; this proximal zebra stripe promoter region contains at least 15 proteinbinding sites (Topol et al. 1987; Dearolf et al., unpubl.). Additional elements responsible for nervous tissue expression are located between $-2.45 \mathrm{~kb}$ and $-669 \mathrm{bp}$ and an enhancer element resides between -6.1 and $-3.4 \mathrm{~kb}$. 
We are interested in elucidating the mechanism by which the zebra stripe pattern of $f t z$ expression is regulated transcriptionally. In this paper we use P-elementmediated transformation with $f t z-l a c Z$ fusion genes to examine the effects of removing relatively small amounts of DNA from the proximal promoter region. We find that the zebra stripe promoter region contains multiple activator and repressor elements. The majority of activator elements appear to be recognized by transcription factors present throughout most of the embryo, in nuclei and cells of both the presumptive odd- and even-numbered parasegments; in addition, one particular activator element functions primarily in the most posterior parasegments. Repressor elements are recognized by factors that negate the action of activators in the odd-numbered parasegments. Also, our results indicate that the upstream enhancer element functions primarily in presumptive epidermal cells. From these observations, we propose a mechanism for the transcriptional regulation of the $f t z$ zebra stripe pattern.

\section{Results}

\section{$\mathrm{ftz}$ transcription start site}

Transcription of $f t z$ DNA in vitro using $\mathrm{K}_{\mathrm{c}}$ cell and embryonic nuclear extracts indicated that the reported TATA homologies and start point of transcription (Laughon and Scott 1984) could be deleted without noticeably reducing the amount of RNA synthesized (Topol et al. 1987). These sequences are also unnecessary for the production of functional transcripts in vivo (this study). To ascertain the start point of transcription, a primer-extension analysis was performed. The result of this analysis is shown in Figure 1. Reverse transcription of both poly $(\mathrm{A})^{+}$and in vitro transcribed $f t z$ RNA begins at a position $50 \mathrm{bp}$ downstream of that reported previously, $-70 \mathrm{bp}$ from the expected start point of translation. The DNA sequence around this initiation site, CTCATTC, is similar to an insect consensus sequence, ATCA $(\mathrm{G} / \mathrm{T} \mid \mathrm{T} / \mathrm{C} / \mathrm{T})$ (Hultmark et al. 1986). There is a TATATAT sequence present $26 \mathrm{bp}$ upstream of the transcription start point.

\section{Experimental approach}

We have constructed $f t z-l a c Z$ fusion genes to localize individual regulatory elements within the zebra-stripe promoter region (Fig. 2A-D). Four series of constructs are described here: $5^{\prime}$ deletions of the ftz promoter, $3^{\prime}$ deletions ligated to the $\mathrm{ftz}$ TATA homology and untranslated leader, a $3^{\prime}$ deletion ligated to the $h s p 70$ TATA homology and leader, and $5^{\prime}$ deletions ligated adjacent to the $f t z$ upstream element, which contains the enhancer element. These constructs were introduced into the genome by P-element-mediated transformation (Rubin and Spradling 1982), and eight independent transformant lines were established for each construct. The expression pattern of each transformant line was examined by X-Gal staining of embryos. Because $\beta$-galactosidase activity is more stable than $f t z$ transcripts and proteins, the product of the fusion genes could be detected as late as the completion of germ-band retraction. To compensate for the different promoter strengths of the constructs, embryos were stained for different lengths of time. For reference, the level of $\beta$-galactosidase activity in transformed lines was also quantitated. Three to five homozygous viable and fertile lines for each construct were selected, and the amount of $\beta$-galactosidase activity in staged embryos was determined spectrophotometrically (Table 1).

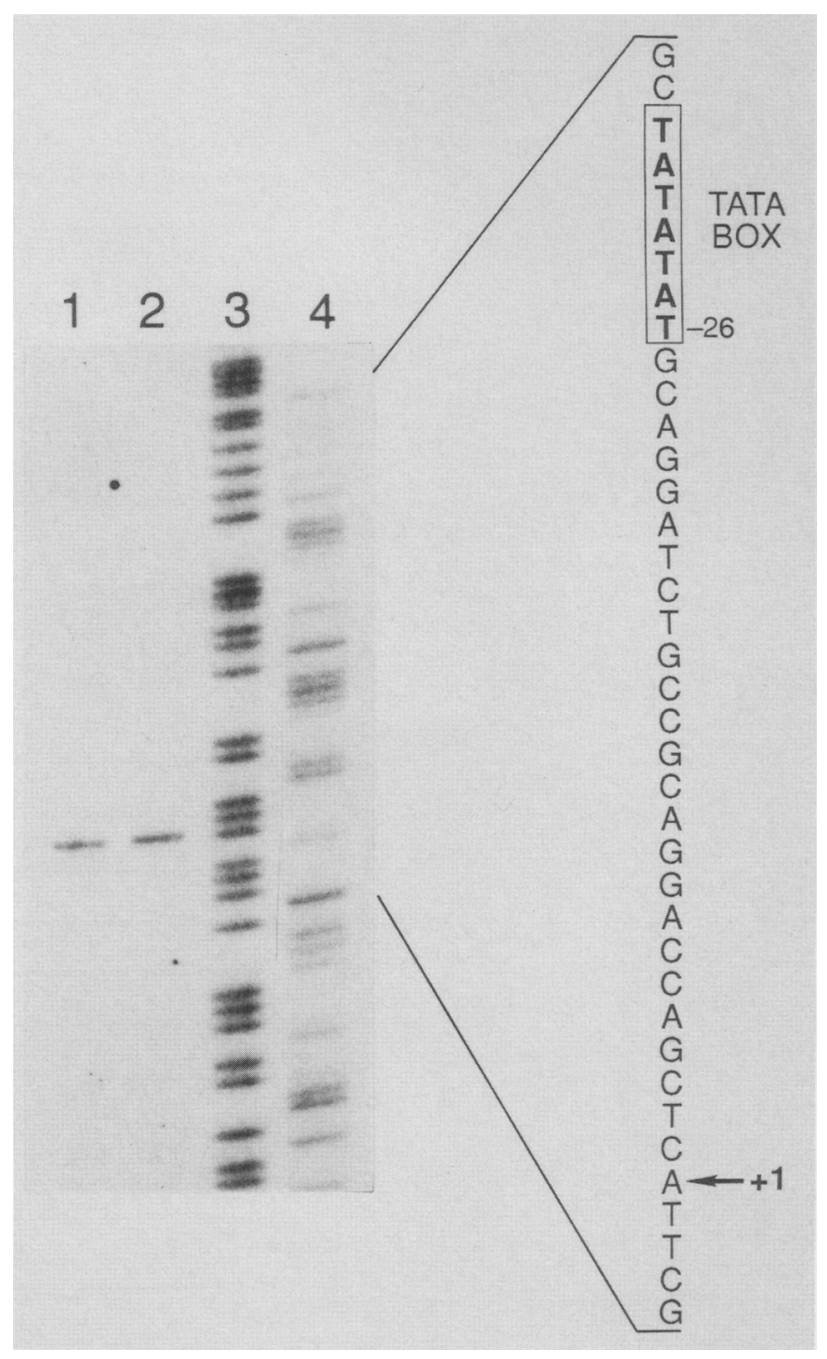

Figure 1. Determination of the transcription start site of the $f t z$ gene. $f t z$ RNA was primer extended, and the reaction products electrophoresed on a $6 \%$ acrylamide, $8 \mathrm{M}$ urea gel. The primer was a ${ }^{32} \mathrm{P}$-end-labeled synthetic oligonucleotide complementary to the $f t z$ transcript between positions +105 to +124 bp. (Lane 1) Reverse transcription of $10 \mu \mathrm{g}$ of poly(A) ${ }^{+}$RNA from 0- to 12-hr embryos. (Lane 2) Reverse transcription of RNA synthesized in vitro from the $f t z$ template with a 0 - to 12-hr embryonic nuclear extract. (Lanes 3,4) The corresponding $f t z$ DNA sequence, chemical cleavage (Maxam and Gilbert 1980 ) of $f t z$ genomic DNA labeled at the RsaI site at $+124 \mathrm{bp}$, specific for pyrimidines (lane 3) and for purines (lane 4). The reverse transcriptase-generated band is elevated 1.5 bp relative to the sequencing standards because of the difference in migration between these fragments (Sollner-Webb and Reeder 1979). 


\section{Dearolf et al.}

Analysis of the zebra stripe promoter

The $5^{\prime} \Delta-669$ gene (Fig. 2A) is expressed primarily in the mesoderm of each of the even-numbered parasegments (Fig. 3A,B; Hiromi et al. 1985). The first stripe is gener- ally the weakest. In addition, examination of understained embryos indicates that the seventh stripe is consistently either the strongest or one of the strongest stripes (data not shown). Interestingly, this seventh

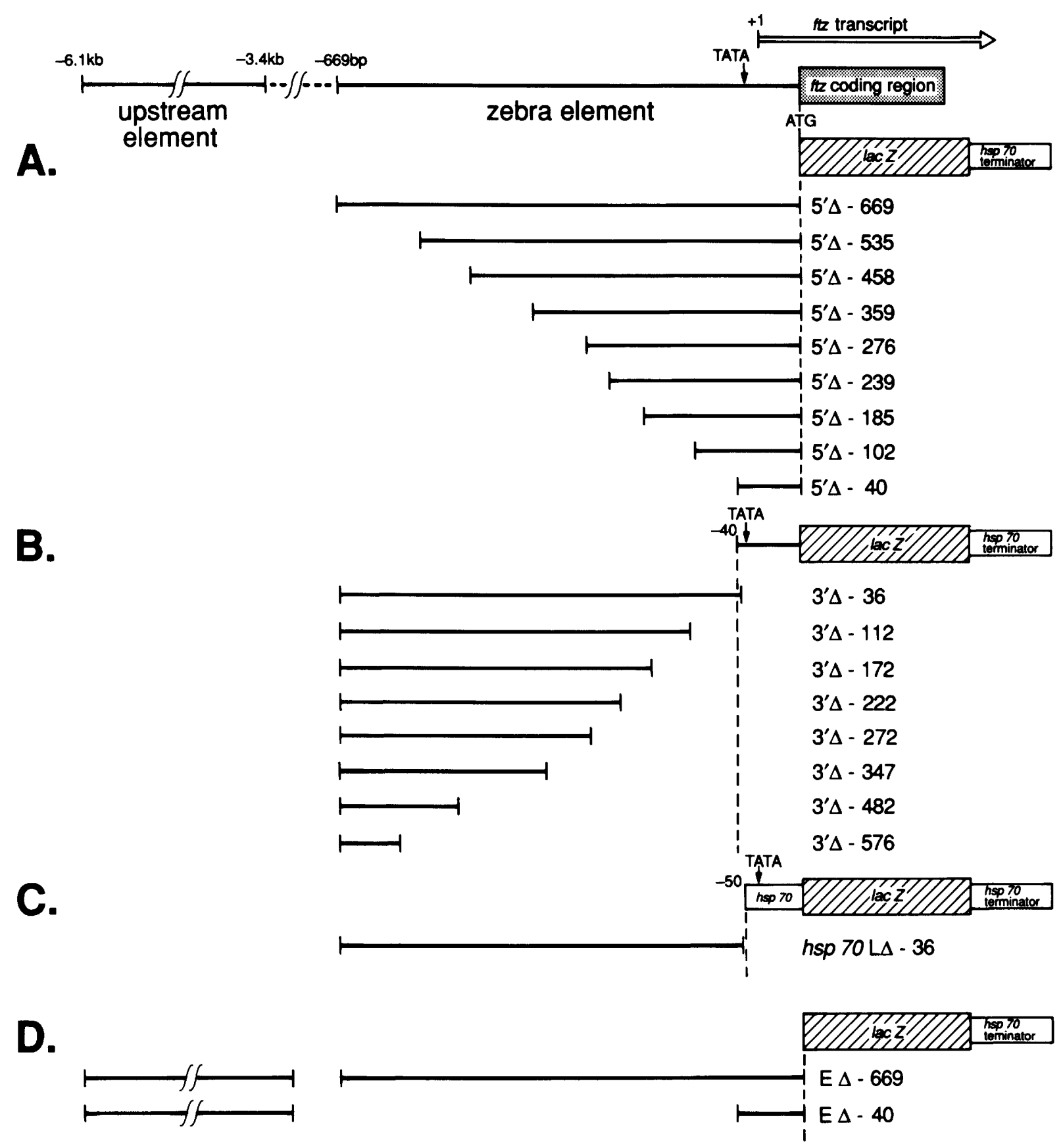

Figure 2. $f t z-l a c Z$ fusion genes used for transformation. (Top) Location of promoter elements necessary for $f t z$ expression in its seven-stripe pattern. The TATA homology is at $-26 \mathrm{bp}$, and the start point of translation is at $+70 \mathrm{bp}$. $(A-D)$ The $f t z$ constructs, inserted into Carnegie 20, used for transformation. Solid horizontal lines represent the $f t z$ sequences included. The constructs are named such that the number following the $\Delta$ indicates the deletion end point from the start point of transcription. $(A) 5^{\prime}$ deletion series of $f t z-l a c Z$. $5^{\prime} \Delta-669$ contains the complete zebra stripe element of Hiromi et al. (1985). (B) $3^{\prime}$ deletion series. ftz promoter fragments were ligated to $5^{\prime} \Delta-40$. All $3^{\prime}$ deletions have a $5^{\prime}$ end point at $-669 \mathrm{bp}$. $(C) h s p 70 \mathrm{~L} \Delta-36$. The deletion fragment from $3^{\prime} \Delta-36$ was inserted upstream of the $h s p 70$ basal promoter. $(D)$ Enhancer series. $5^{\prime} \Delta-669$ and $5^{\prime} \Delta-40$ were inserted $3^{\prime}$ to the $2.7-\mathrm{kb}$ upstream enhancer element. 
Table 1. Expression of $\mathrm{ftz}-\mathrm{lacZ}$ constructs

\begin{tabular}{|c|c|c|c|c|}
\hline \multirow[b]{2}{*}{ Construct } & \multirow{2}{*}{$\begin{array}{l}\text { Number of } \\
\text { transformant } \\
\text { lines quantitated }\end{array}$} & \multicolumn{2}{|c|}{ Units of $\beta$-galactosidase activity ${ }^{\mathbf{a}}$} & \multirow{2}{*}{$\begin{array}{l}\text { Level of } \\
\text { derepression }\end{array}$} \\
\hline & & mean \pm S.D. & range & \\
\hline $5^{\prime} \Delta-669$ & 5 & $914 \pm 157$ & $744-1131$ & none \\
\hline $5^{\prime} \Delta-535$ & 5 & $824 \pm 255$ & $576-1193$ & none \\
\hline $5^{\prime} \Delta-458$ & 4 & $544 \pm 219$ & $348-847$ & none \\
\hline $5^{\prime} \Delta-359$ & 5 & $225 \pm 66$ & $139-315$ & none \\
\hline $5^{\prime} \Delta-276$ & 3 & $112 \pm 19$ & $91-127$ & mild \\
\hline $5^{\prime} \Delta-239$ & 5 & $215 \pm 42$ & $174-263$ & moderate \\
\hline $5^{\prime} \Delta-185$ & 5 & $119 \pm 26$ & $86-145$ & moderate \\
\hline $5^{\prime} \Delta-102$ & 4 & $42 \pm 35$ & $8-87$ & strong \\
\hline $5^{\prime} \Delta-40$ & 5 & $8 \pm 9$ & $2-18$ & $\mathrm{NA}^{\mathrm{b}}$ \\
\hline $3^{\prime} \Delta-36$ & 4 & $520 \pm 90$ & $457-650$ & none \\
\hline $3^{\prime} \Delta-112$ & 3 & $449 \pm 109$ & $323-519$ & none \\
\hline $3^{\prime} \Delta-172$ & 5 & $412 \pm 52$ & $337-463$ & mild \\
\hline $3^{\prime} \Delta-222$ & 5 & $264 \pm 112$ & $141-415$ & moderate \\
\hline $3^{\prime} \Delta-272$ & 5 & $391 \pm 242$ & $119-635$ & moderate \\
\hline $3^{\prime} \Delta-347$ & 5 & $97 \pm 46$ & $31-158$ & strong \\
\hline $3^{\prime} \Delta-482$ & 5 & $46 \pm 16$ & $25-67$ & $\mathrm{NA}^{\mathrm{b}}$ \\
\hline $3^{\prime} \Delta-576$ & 3 & $5 \pm 9$ & $0-16$ & $N^{b}{ }^{b}$ \\
\hline hsp 70L $\Delta-36$ & 4 & $176 \pm 25$ & $142-204$ & none \\
\hline$E \Delta-669$ & 3 & $1566 \pm 347$ & $1174-1831$ & - \\
\hline $\mathrm{E} \Delta-40$ & 5 & $110 \pm 49$ & $43-160$ & - \\
\hline
\end{tabular}

a Each unit of $\beta$-galactosidase activity is equivalent to one $\mathrm{OD}_{574}$ unit/mg protein $\times 10^{2}$. The background value of 47 units for untransformed ry embryos was subtracted from each value. The value for each transformant line was obtained from measurement of two separate egg collections.

b (NA) Derepression could not be assayed in these transformant lines due to the low levels of $\beta$-galactosidase activity.

stripe is the widest when $f t z$ protein is localized by antibody staining (Carroll and Scott 1985 ). The $5^{\prime} \Delta-669$ construct is also expressed in the ectoderm but in lower levels relative to E $\Delta-669$ (Fig. 2D), which contains both the upstream element and the zebra stripe element (Fig. $5 \mathrm{~A}, \mathrm{~B})$. In both cases, ectodermal staining is found in the anterior portion of the even-numbered parasegments. During germ-band extension, when mesodermal and ectodermal parasegments are in register, ectodermal stripes align primarily with the anterior part of the mesodermal stripes. Following germ-band retraction, parasegments in the mesoderm are shifted approximately one-half segment caudally, relative to those in the ectoderm (Martinez-Arias and Lawrence 1985; Fig. 3B). At this stage, ectodermal staining is localized in narrow bands in the posterior segmental compartments (anterior parasegmental compartments), whereas mesodermal staining appears in broader bands throughout most of the segment just posterior to the ectodermal stripes. This shift in mesodermal staining also can be observed in Figures 3, F, H and 4, C,E, G, in which mesodermal stripes are located between the segmental grooves following germ-band retraction. A similar shift has been observed for the expression of Ultrabithorax $(U b x)$ (Akam and Martinez-Arias 1985). Staining is seen also on the ventral side anterior to the cephalic furrow, as reported previously (Hiromi et al. 1985).

\section{Expression of the $5^{\prime}$ deletion constructs}

To determine the effects of deleting short regions of the $f t z$ promoter, the expression of each of the $5^{\prime}$ and $3^{\prime} f t z-$ lac $Z$ progressive deletions was compared to that of the fusion gene preceding it in the series. The comparisons are based on examination of X-Gal staining in the germ band of the embryos. Because expression anterior to the cephalic furrow is variable, we do not include the staining in this region in our analysis.

No change in pattern or amount of stain is seen between embryos transformed with $5^{\prime} \Delta-669$ and with $5^{\prime} \Delta-535$ (data not shown). Deleting to -458 bp causes the overall level of expression to decrease compared with $-535 \mathrm{bp}$, as both mesodermal and ectodermal expression levels are reduced in each of the stripes (Fig. 3C; Fig. 6, activator element A1). Deleting to $-359 \mathrm{bp}$ additionally reduces the level of expression (Fig. 3D, Fig. 6, activator element A2). Deleting to -276 bp causes expression levels to decrease further, and only mesodermal stain can be detected (Fig. 3E,F; Fig. 6, activator element A3). Interestingly, ectopic mesodermal expression is observed also. A portion of cells in the odd-numbered parasegments express the fusion gene, causing each of the bands during germ-band extension to appear broadened (Fig. 3E; Fig. 6, repressor element R1). This ectopic expression is even more noticeable in embryos following germ-band retraction (Fig. 3F). Deleting to -239 bp (Fig. $3 \mathrm{G}, \mathrm{H}$; Fig. 6, repressor element R2) causes cells of the odd-numbered parasegments to stain even more intensely than in $5^{\prime} \Delta-276$ embryos; again, this is most evident following germ-band retraction (Fig. $3 \mathrm{H}$ ). Deleting further to $-185 \mathrm{bp}$ does not change the staining pattern (Fig. 3I), although the total level of expression is lower when assayed spectrophotometrically (Table 1). Deleting to $-102 \mathrm{bp}$ causes the level of stain to decrease 
Dearolf et al.
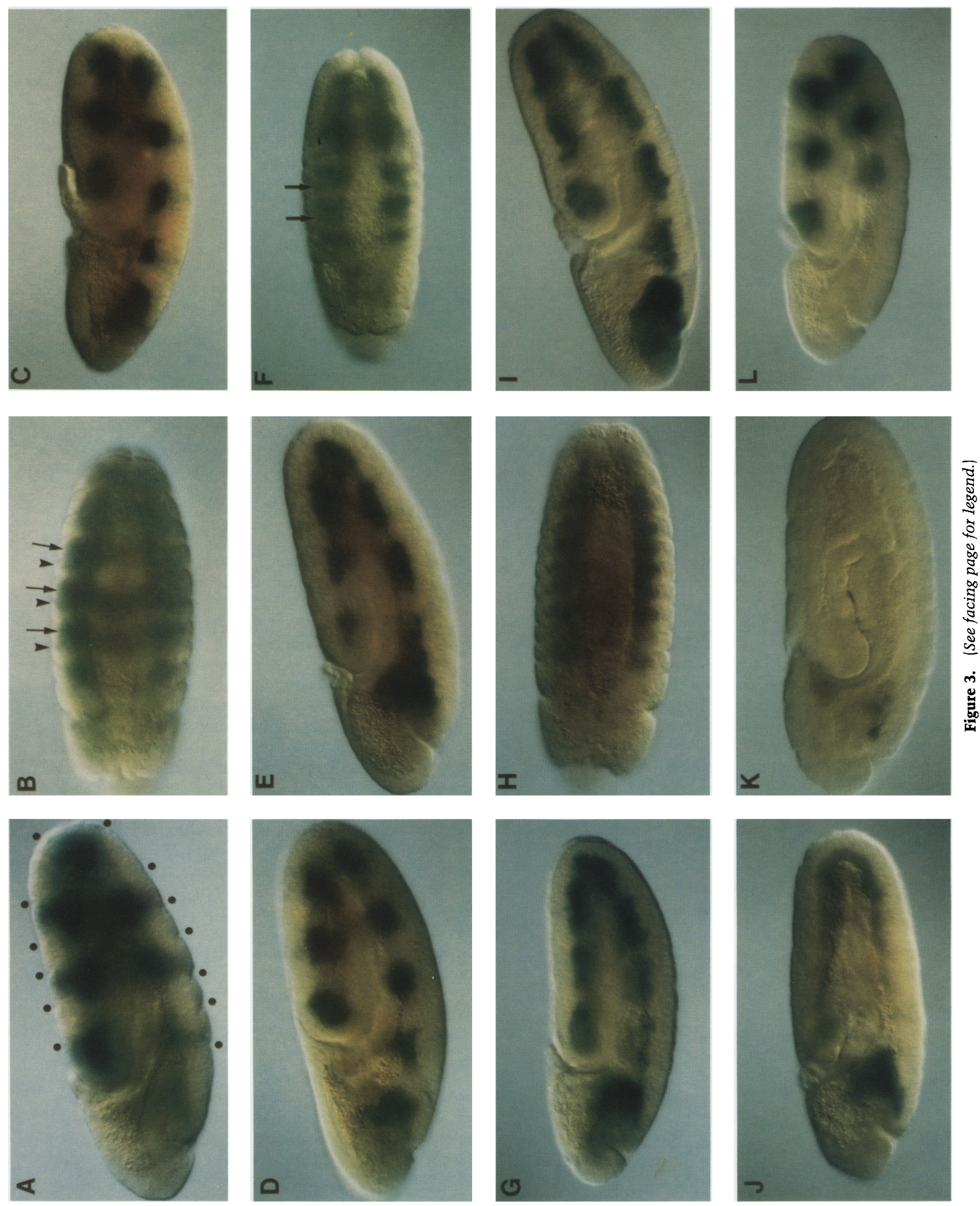
dramatically (Fig. 3J; Fig. 6, activator element A4). Low levels of mesodermal stain are seen throughout the length of the germ band, but definitive stripes are not observed (Fig. 6, repressor element R4). Deleting to -40 bp causes the loss of all stain, except that anterior to the cephalic furrow (Fig. 3K, Fig. 6, activator element A5).

\section{Expression of the $3^{\prime}$ deletion constructs}

The $3^{\prime}$ deletion constructs were generated by ligating a series of $3^{\prime}$ deleted fragments of the $f t z$ zebra stripe promoter to $5^{\prime} \Delta-40$. We did not control for the position of the inserted promoter fragment relative to the TATA homology and downstream sequences. To determine whether such a shift could influence $f t z-l a c Z$ expression, we included the $3^{\prime} \Delta-36$ fusion in this study. This construct contains the complete zebra stripe promoter, but with sequences upstream of $-36 \mathrm{bp}$ shifted $15 \mathrm{bp}$, approximately one and one-half DNA helical turns (Peck and Wang 1981; Rhodes and Klug 1981). Figure 4A shows that repressor elements are not affected in $3^{\prime} \Delta-36$ embryos, as the pattern of stripes is identical to that generated by $5^{\prime} \Delta-669$. However, the overall level of activity is reduced $\sim 45 \%$ (Table 1 ), indicating that activator elements are sensitive to their distance relative to downstream promoter elements or to their position along the face of the DNA helix.

Deleting to -112 bp does not have a significant effect on the level of stain when compared with $3^{\prime} \Delta-36 \mathrm{em}$ bryos, although the most posterior stripe stains slightly stronger relative to the other stripes (Fig. 4B,C; Fig. 6, activator element A5). Deleting to $-172 \mathrm{bp}$ causes a more pronounced alteration in the relative band strengths (Fig. 4D,E; Fig. 6, activator element A4). Stripe 7 is considerably darker than the other stripes, and the expected stripe in parasegment 2 is weak or absent. Stain is restricted generally to the mesoderm. In addition, a slight loss of interband repression is observed, which is most evident following germ-band retraction (Fig. 6, repressor element R4). Ectopic expression is strongest in the posterior odd-numbered parasegments, although expression in all odd-numbered parasegments can be seen upon overstaining the embryos (data not shown). Deleting to $-222 \mathrm{bp}$ causes a further loss of repression (Fig. 4F,G; Fig. 6, repressor element R3). During germ-band extension, staining is observed in a continuous band in the mesoderm, with stronger expression in the evennumbered parasegments. Following germ-band retraction, the ectopic stripes are darker relative to those in $3^{\prime} \Delta-172$ embryos. Expression in the posterior parasegments continues to be stronger than in parasegments 1-4. Deleting to -272 has no further effect (Figs. $4 \mathrm{H}, \mathrm{I}$ ). Deleting to $-347 \mathrm{bp}$ greatly decreases the amount of expression (Fig. 4J; Fig. 6, activator element $\mathrm{A} 3$ and repressor element $R 1$ ). In addition, all interband repression appears to be lost. Deleting to $-482 \mathrm{bp}$ further reduces the expression of $f t z-l a c Z$, particularly in the posterior parasegments. Only a light line of mesodermal stain can be seen in the germ band, with the stain slightly more visible in the region where stripes 4 and 5 would be found normally (Fig. $4 \mathrm{~K}$; Fig. 6, activator element A2). Deleting to $-576 \mathrm{bp}$ eliminates detectable expression in the germ band, similar to the $5^{\prime} \Delta-40$ construct (Fig. $4 L_{\text {; }}$ Fig. 6, activator element Al).

To test whether sequences in the $f t z$ untranslated leader are necessary for the zebra stripe pattern of expression, $f t z$ sequences from -669 to -36 bp were also inserted into HZ50PL (Hiromi and Gehring 1987), which contains the $h s p 70$ TATA homology and untranslated leader (Fig. 2C). As shown in Fig. 3L, the striped pattern of $\beta$-galactosidase expression is still generated in embryos transformed with this construct, indicating that sequences downstream of $-36 \mathrm{bp}$ are not essential for the repression of $f t z$ expression in the odd-numbered parasegments. However, the overall level of expression is reduced in $h s p 70 \mathrm{~L} \Delta-36$ embryos compared to the expression of the $3^{\prime} \Delta-36$ construct (Table 1), with stripes 3 , 4 , and 5 consistently the strongest. We do not know whether these alterations are due to the removal of specific $f t z$ sequences located close to the cap site or in the untranslated leader or to an artificial decrease in transcriptional efficiency resulting from the inclusion of heterologous promoter sequences.

\section{The upstream enhancer element functions only in epidermal cells}

The 2.7-kb upstream element contains an enhancer element through which $f t z$ increases its own transcription (Hiromi and Gehring 1987). As part of a related series of experiments, we inserted this upstream element $5^{\prime}$ to

Figure 3. $f t z-l a c Z$ expression of $5^{\prime}$ zebra stripe deletion constructs and of $h s p 70 \mathrm{~L} \Delta-36$. Localization of $\beta$-galactosidase expression in whole-mount transformant embryos. $(B, F, H)$ A ventral view of embryos following germ-band retraction (stage 13 of Campos-Ortega and Hartenstein 1985). All other embryos shown were examined during germ-band extension (stages 8-11). A more detailed description of the expression patterns is given in the text. $(A, B) 5^{\prime} \Delta-669$ embryos. Expression is strongest in the mesoderm, although stain is present in the anterior portion of parasegments in the ectoderm. The transient parasegmental grooves are indicated by closed circles. Following germ-band retraction $(B)$, the ectodermal stain (arrowheads) is anterior to that in the mesoderm (arrows). (C) $5^{\prime} \Delta-458$ embryo. $(D) 5^{\prime} \Delta-359$ embryo. $(E, F) 5^{\prime} \Delta-276$ embryos. Ectopic expression is seen as broadened bands during germ-band extension $(E)$ and as additional stripes following germ-band retraction $(F)$ (examples of ectopic expression are indicated by arrows). $(G, H) 5^{\prime} \Delta-239$ embryos. (I) 5' $\Delta-185$ embryo. (J) 5' $\Delta-102$ embryo. (K) 5' $\Delta-40$ embryo. $(L)$ hsp $70 \mathrm{~L} \Delta-36$ embryo.

Figure 4. (See p. 390.) ftz-lacZ expression of $3^{\prime}$ zebra stripe deletion constructs. Localization of $\beta$-galactosidase expression in wholemount transformant embryos. ( $C, E, G$, and $I)$ Embryos following germ-band retraction, whereas all other embryos are shown during germ-band extension. (A) 3' $\Delta$-36 embryo. $(B, C) 3^{\prime} \Delta-112$ embryos; $(D, E) 3^{\prime} \Delta-172$ embryos. In $D$, note the absence of stain in parasegment 2 (open arrow) and the strong stain in the posterior parasegments. In $E$, examples of ectopic expression are indicated by arrows. $(F, G) 3^{\prime} \Delta-222$ embryos; $(H, I) 3^{\prime} \Delta-272$ embryos; (J) 3' $\Delta-347$ embryo; $(K) 3^{\prime} \Delta-482$ embryo; $(L) 3^{\prime} \Delta-576$ embryo. 
Dearolf et al.
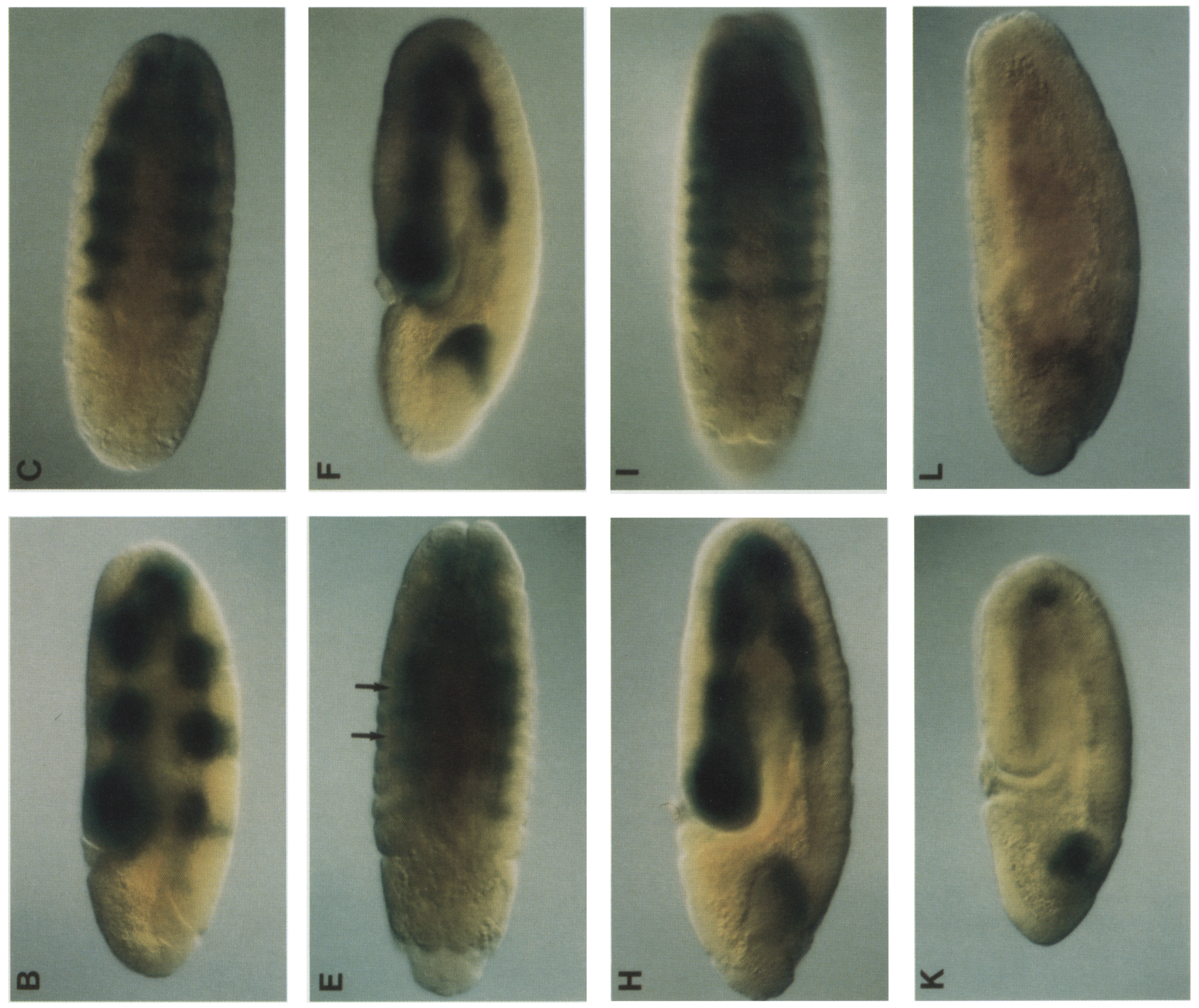

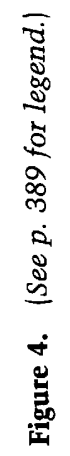
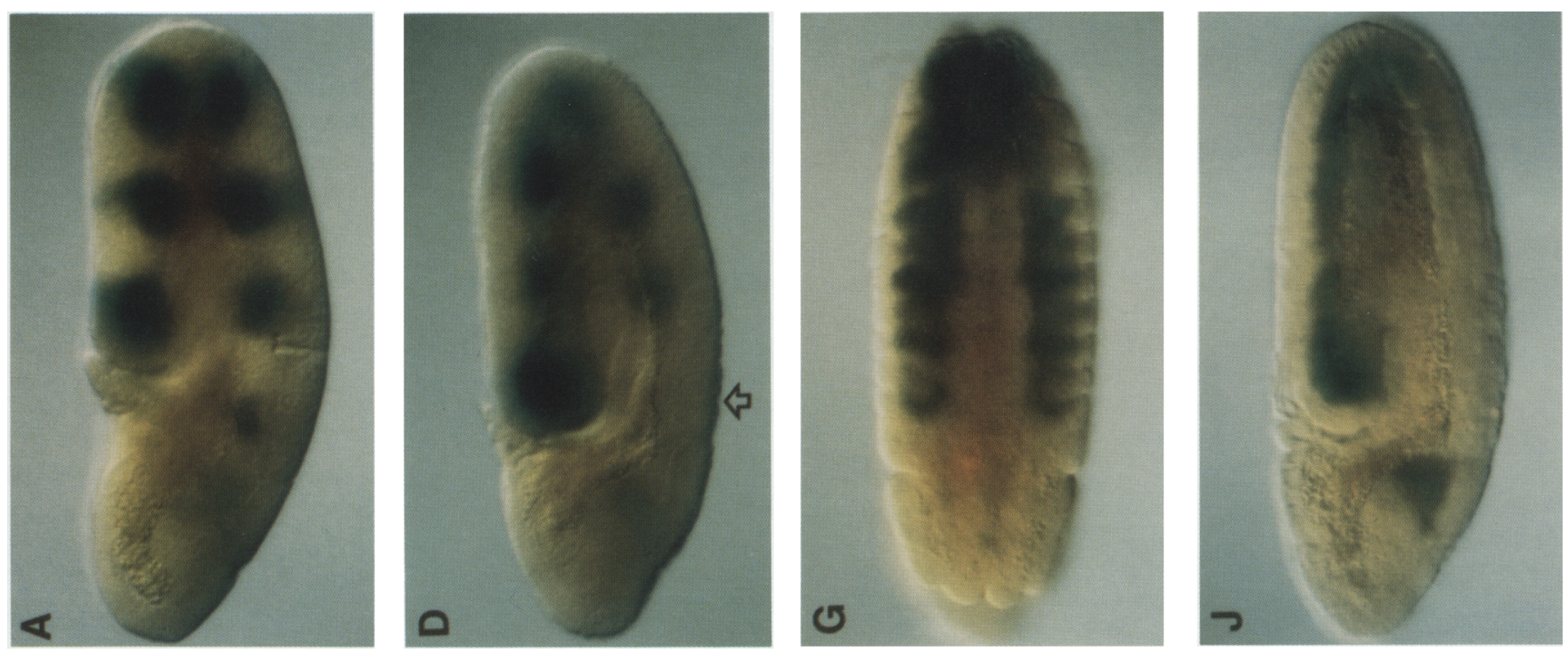

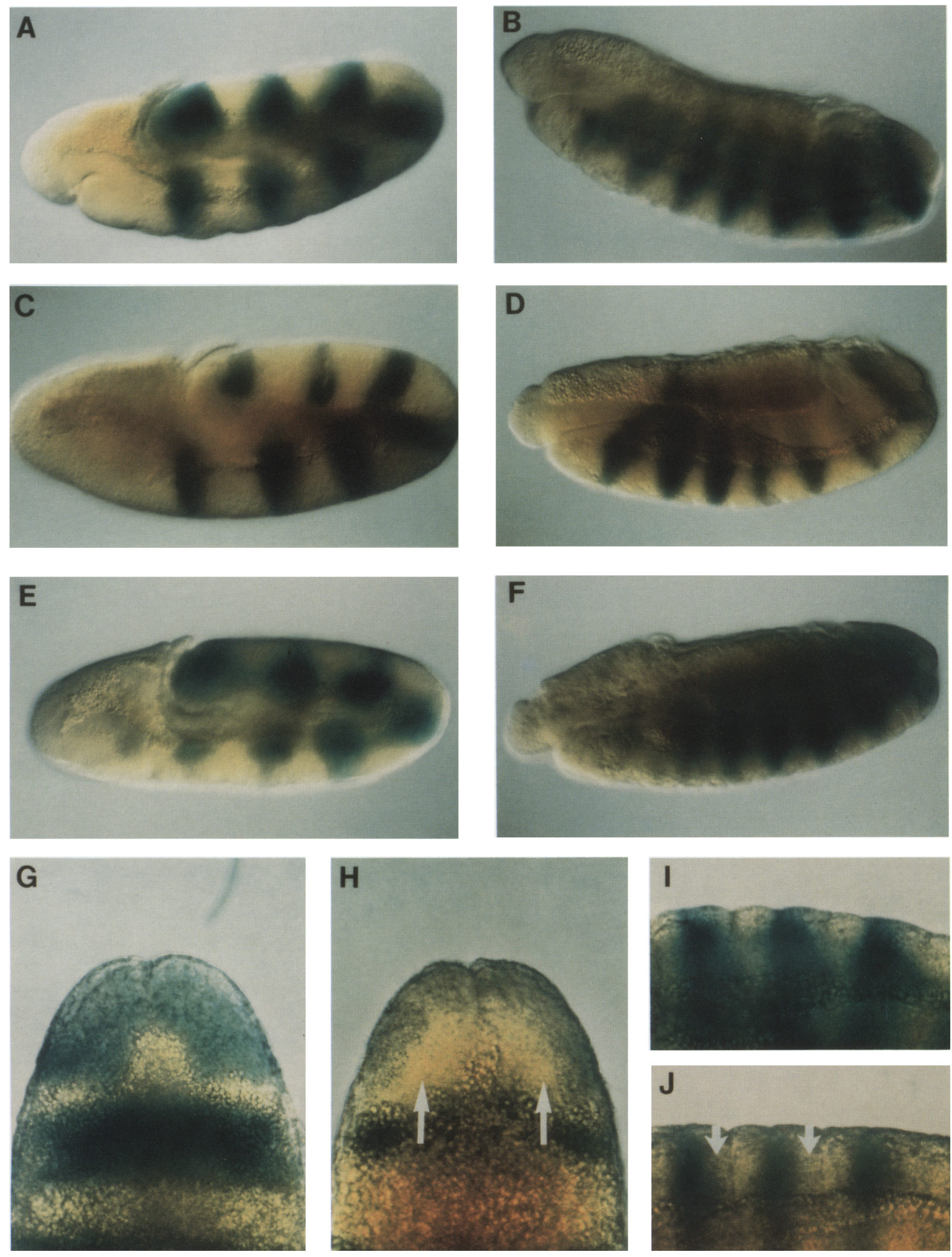

Figure 5. (See p. 392 for legend.) 
both $5^{\prime} \Delta-669$ and $5^{\prime} \Delta-40$ (Fig. 2D). Although ectodermal expression is found in both $\mathrm{E} \Delta-669$ and $\mathrm{E} \Delta-40$ embryos (Fig. 5A-D), the latter construct is not expressed in mesodermal cells (cf. Fig. 5, G,I to H,J) or in the nervous system (Hiromi and Gehring 1987). This indicates that expression dependent on the upstream element is restricted to epidermal cells. The $\mathrm{E} \Delta-40 / \mathrm{lac} Z$ stripes are not found in embryos homozygous for $\mathrm{ftz}^{9 \mathrm{H} 34}$, a strong allele, verifying that the $E \Delta-40$ expression is the result of $f t z$ mediated enhancer activity (data not shown).

\section{Discussion}

\section{Activator and repressor elements}

Our results indicate that the $f t z$ zebra stripe promoter is a complex composite of multiple activator and repressor elements that contribute to the regulation of $f t z$ expression. We find at least five activator and four repressor elements whose removal can be detected in individually stained embryos in the sequences between -669 and $-36 \mathrm{bp}$ of the $f t z$ transcription unit. The deletion end points that remove the function of these elements are presented in Figure 6.

The deletion of activator elements results in a reduction of $f t z-l a c Z$ expression. This decrease can be seen most clearly in the $5^{\prime}$ deletion constructs. The majority of the activator elements appear to allow a similar level of expression in most parasegments, although the level is slightly weaker in the stripes at either terminus of the germ band (e.g., see Fig. 3D,E,G,I). In contrast, one additional activator element (A2) provides transcriptional activity preferentially in the posterior parasegments, particularly in those cells that comprise the seventh stripe. The positional specificity of element $\mathrm{A} 2$ is most noticeable in constructs that contain A2 and only one or two general activator elements $\left(3^{\prime} \Delta-172,3^{\prime} \Delta-222,3^{\prime} \Delta-272\right.$, and $\left.3^{\prime} \Delta-347\right)$. Furthermore, a posterior preference is not seen in fusion genes that lack the A2 activator element but contain general activator elements $\left(3^{\prime} \Delta-482 ; 5^{\prime} \Delta-359\right.$ to $\left.5^{\prime} \Delta-102\right)$.

It is important to note that reductions in promoter strength are not due simply to the nonspecific removal of $f t z$ DNA. Deleting $134 \mathrm{bp}$ between $5^{\prime} \Delta-669$ and $5{ }^{\prime} \Delta-535$ does not alter the amount of expression significantly, and deleting a repressor element between $5^{\prime} \Delta-276$ and $5^{\prime} \Delta-239$ actually increases the total amount of expression (Table 1). Hence, significant differences in the level of expression among the $5^{\prime}$ constructs most probably represent the effects of deleting $f t z$ regulatory elements. The analysis of several activator elements in the $3^{\prime}$ deletion series is more complicated because of the nature of the constructs. The deletion of activator elements A4 and A5 in the $3^{\prime}$ construct series does not lower the overall level of expression. Presumably this is due to the different positions of upstream sequences relative to the TATA homology and start point of transcription among the $3^{\prime}$ deletion constructs. Nevertheless, the effects of removing these activator elements can be seen as changes in relative expression levels among the parasegments, rather than as changes in absolute levels, as described above.

The deletion of repressor elements permits ectopic $f t z-l a c Z$ expression in cells of each of the odd-numbered parasegments. Removing one repressor element from either the $5^{\prime}$ or $3^{\prime}$ direction causes a mild loss of repression; this effect is seen as a slight broadening of the stripes during germ-band extension and/or as the presence of lightly staining ectopic stripes after germ-band retraction (Figs. 3E,F and 4E). Deleting a second repressor element results in stronger ectopic expression (Figs. 3G,H and 4F,G). Removing at least four of the repressor elements allows the $f t z-l a c Z$ constructs to be expressed equally in the odd- and even-numbered parasegments; a continuous band of mesodermal expression is observed in $3^{\prime} \Delta-347$ embryos (Fig. $\left.4 \mathrm{~J}\right)$ and in $5^{\prime} \Delta-102$ embryos (Fig. 3J), although the latter expression is sometimes difficult to observe because of the low activation level in these embryos.

It is possible that the $f t z$ zebra stripe promoter may contain activator and repressor elements not identified here. The quantitation data show a reduction of $\sim 45 \%$ in $\beta$-galactosidase activity between $5^{\prime} \Delta-239$ and $5^{\prime} \Delta-185$ (Table 1), suggesting the presence of an activator element that cannot be detected in an examination of individually stained embryos. Also, the presence of multiple activator or repressor elements within an identified regulatory region would not be detected. Furthermore, we have not examined the effects on expression of $f t z$ sequences upstream of $-669 \mathrm{bp}$ and cannot rule out the possibility that sequences in the $2.7-\mathrm{kb}$ upstream element may contain regulatory elements other than the enhancer.

\section{Comparison of $\mathrm{ftz}$ expression in the mesoderm and ectoderm}

Ectodermal parasegments are divided during development into anterior and posterior compartments, whereas mesodermal parasegments do not appear to develop these clonal restrictions (Martinez-Arias and Lawrence 1985). It is not surprising that in the mesoderm, the $\mathrm{ftz}$ zebra stripe promoter is expressed in similar amounts

Figure 5. Effects of the upstream promoter element on $f t z-l a c Z$ expression. Whole-mount transformant embryos were stained for $\beta$-galactosidase activity during germ-band extension $(A, C, E, G, H)$ or following germ-band retraction $(B, D, F, I, J) .(A, B) \mathrm{E} \Delta-669$ embryos, which contain both the upstream enhancer element and zebra stripe element fused to lac $Z$, stain well in both the ectoderm and mesoderm. $(C, D) \mathrm{E} \Delta-40$ embryos, which contain only the upstream element fused to lac $Z$, do not stain in the mesoderm. $(G-J)$ Higher magnification of $\mathrm{E} \Delta-669$ embryos $(G, I)$ and $\mathrm{E} \Delta-40$ embryos $(H, J)$. Note the absence of mesodermal stain in $H$ and $J$ (arrows). (E-F) Included for comparison are $5^{\prime} \Delta-669$ embryos, which contain only the zebra stripe element fused to lacZ. Stain is strongest in the mesoderm but is present in lower levels in the ectoderm. 

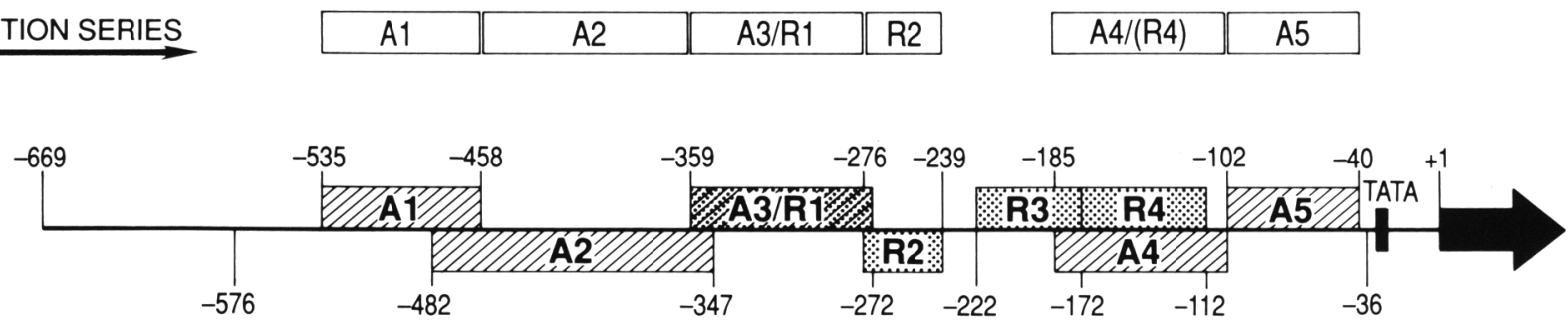

3. DELETION SERIES

\begin{tabular}{|l|l|l|}
\hline$A 1$ & $A 2$ & $A 3 / R 1$ \\
\hline
\end{tabular}

\begin{tabular}{|l|l|l|}
\hline R3 & R4/(A4) & (A5) \\
\hline
\end{tabular}

Figure 6. Location of $f t z$ activator and repressor elements in the zebra stripe promoter. (Top) The deletion end points that remove activator elements $(\mathrm{A} 1-\mathrm{A} 5)$ and repressor elements $(\mathrm{R} 1-\mathrm{R} 4)$ are shown. The $5^{\prime}$ deletion series end points and the elements they remove; (bottom) those of the 3' deletion series. An activator element is designated between the end points of those constructs in which the level of $f t z-l a c Z$ expression decreases noticeably when comparing stained embryos by light microscopy. A repressor element is designated when ectopic expression appears or increases in odd-numbered parasegments. The middle diagram integrates the results of both the $5^{\prime}$ - and $3^{\prime}$-deletion series. The location of activator elements is shown as hatching, and that of repressor elements as dots. The effects of deleting elements A4 and A5 in the $3^{\prime}$ direction and element R4 in the $5^{\prime}$ direction are masked partially, and are therefore indicated in parentheses (discussed further in text).

throughout the length of the even-numbered parasegments. In contrast, ectodermal ftz-lac $Z$ expression is detected primarily in the anterior part of parasegments (Figs. 3A,B and 5A-F), in cells comprising the posterior segmental compartments (Lawrence et al. 1987; Carroll et al. 1988a), with only minor staining in the posterior part of parasegments.

The zebra stripe activator elements are transcriptionally active in both ectodermal and mesodermal cells. Deleting activator elements in either the $5^{\prime}$ or $3^{\prime}$ direction causes a sequential loss of expression in both ectoderm and mesoderm. Detection of ectodermal expression is lost before that of mesodermal expression in the $5^{\prime}$ and $3^{\prime}$ deletion series (Figs. $3 \mathrm{E}$ and $4 \mathrm{D}$ ) because the overall activation is lower in the ectoderm. Our results do not address whether each repressor element functions in both ectoderm and mesoderm, because ectodermal expression is below the level of detectability in those transformants showing a loss of mesodermal repression.

The activity of the upstream enhancer element is detectable only in epidermal cells (Fig. 5). Hiromi and Gehring (1987) demonstrated that this activity requires the product of the $f t z$ gene but that it does not function in neural cells expressing $f t z$, indicating that at least one additional factor is involved in the transcriptional enhancement. Our results indicate that the enhancer activity is also negligible in cells of the mesoderm, despite the presence of $f t z$ product. This observation supports the idea that the $f t z$ product alone is insufficient to increase transcription of the $f t z$ gene. The $f t z$ protein is found in multiple phosphorylated forms in embryos (Krause et al. 1988), suggesting that tissue-specific modifications could regulate the enhancer-mediated function of this protein. It is not yet known whether $\mathrm{ftz}$ protein enhances transcription of the $f t z$ locus directly or whether it acts through other factors.

\section{Regulation of zebra stripe expression}

Our results suggest that at least two types of transacting activators and one type of repressor regulate $f t z$ transcription through the zebra stripe promoter region. One type of activator recognizes at least the $\mathrm{Al}, \mathrm{A} 3, \mathrm{~A} 4$, and A5 elements and is expressed in nuclei and cells throughout the region of the presumptive germ band. The variety of $f t z$ protein-binding sequences and DNase I footprinting patterns throughout embryogenesis (data not shown) suggests that this type of activator contains multiple members. A second type of activator recognizes the A2 element and functions preferentially in the presumptive posterior parasegments, particularly in the cells that comprise the seventh $f t z$ stripe. Interestingly, we do not find clear evidence for activators that act primarily in the anterior parasegments.

The expression of constructs in which repressor elements have been deleted indicates that both types of activators function in nuclei and cells of the odd-numbered, as well as even-numbered, parasegments. The deletion of repressor elements allows $f t z-l a c Z$ constructs to be transcribed in odd-numbered parasegments at levels proportional to the level of expression in adjacent, even-numbered parasegments (e.g., see Fig. 4G) . This ectopic expression could not occur unless trans-acting transcriptional activators were present in similar levels in both the odd- and even-numbered parasegments.

Our results indicate that the wild-type $f t z$ zebra stripe pattern is refined, to a large extent, by the function of transcriptional repressors, rather than by a loss of activators. This conclusion concurs with those drawn from studies using an inhibitor of protein synthesis (Edgar et al. 1986), although we do not detect the loss of polar repression in the most posterior and dorsal anterior parts of the embryo, as described in those studies. ftz re- 
pressors could negate the contributions of activators by several mechanisms. They could act directly on activator proteins or through $f t z$ promoter sequences to block activation. Both possibilities have been identified in cells of higher eukaryotes (Goodburn et al. 1986; Mitchell et al. 1987). We observe that $f t z$ repressors use the latter mechanism; otherwise, deleting the cis-acting repressor elements would not result in ectopic expression. However, we cannot rule out that there is a subset of repressors not identified here that acts directly on activators. In addition, the lack of ectopic expression in embryos transformed with the $h s p 70 \mathrm{~L} \Delta-36$ construct, which does not contain any $f t z$ transcribed sequences (Fig. 3L), indicates that repressors are not involved in differential regulation of $f t z$ mRNA stability.

We suggest the following mechanism for the control of $f t z$ transcription in early embryos (Fig. 7): ftz activators are functional before repressors during early embryogenesis (Fig. 7A). The majority of activators are expressed in nuclei throughout the presumptive germ band, whereas others are expressed primarily in poste- rior nuclei. This enables $f t z$ transcripts to be expressed initially in a continuous band of nuclei. As ftz repressors become expressed in nuclei that will contribute to the odd-numbered parasegments, $f t z$ transcription continues only in nuclei lacking these negative regulators (Fig. 7B). Because $f t z$ transcripts have a short half-life (Edgar et al. 1987), the pattern of $f t z$ RNAs resolves into the zebra stripe within a short time after the appearance of repressors. At this stage, activators continue to be present in nuclei of both the presumptive odd- and even-numbered parasegments, although these activators could be the products of different genes than those expressed earlier in development. By the cellular blastoderm stage, $f t z$ proteins are translated; these proteins are necessary for the enhancement of $f t z$ transcription through the upstream element in epidermal cells (Fig. 7C).

Determining the precise $f t z$ cis-regulatory sequences would provide a basis for directly identifying activators and repressors of $f t z$ transcription. Most of the regulatory regions demonstrated in this paper contain several protein binding sites, making the identification of the
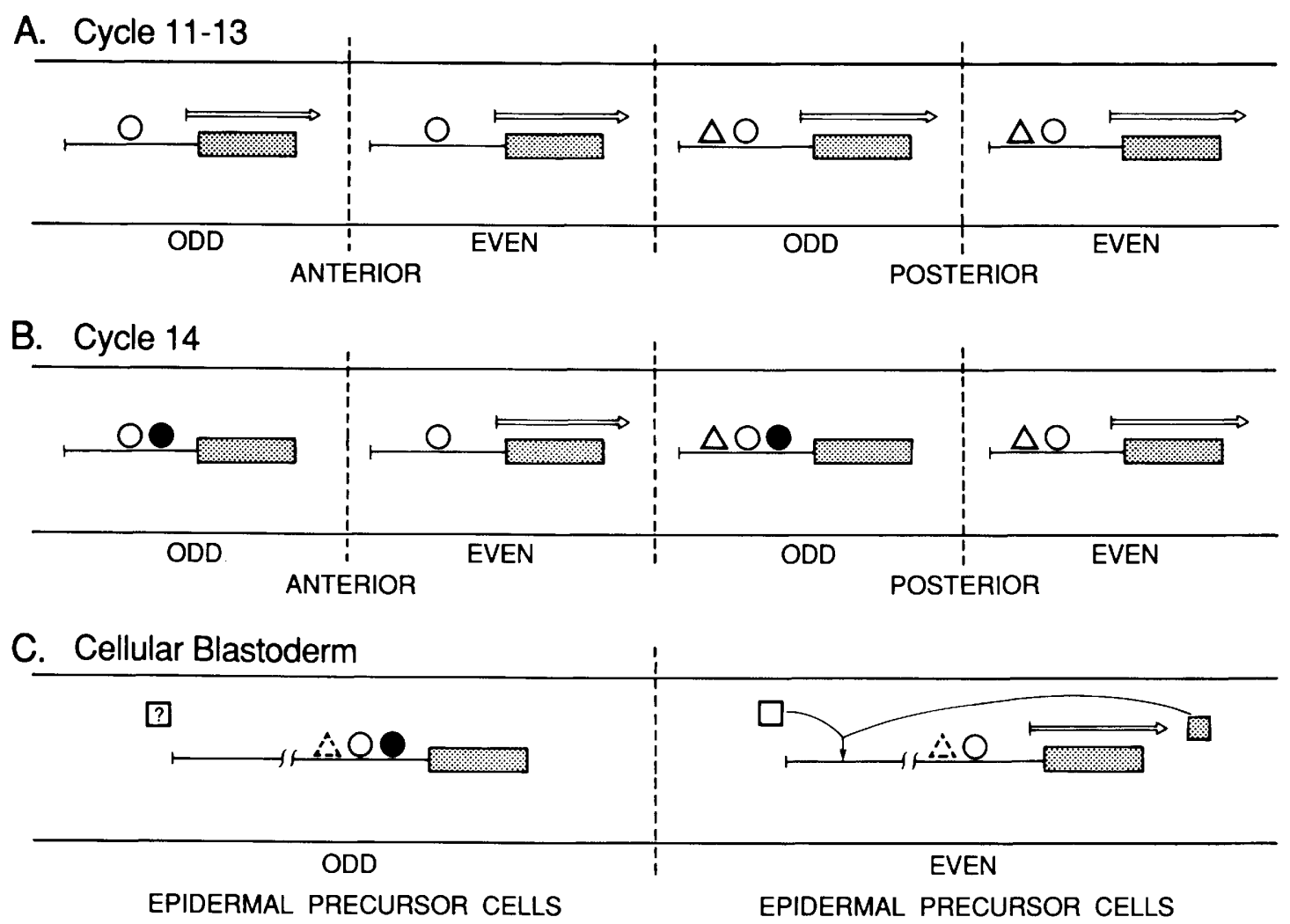

Figure 7. Transcriptional regulation of $f t z$ zebra stripe expression. A model for the establishment of the $f t z$ zebra stripe transcription pattern is given. $(A)$ By cycle $11, f t z$ is transcribed (horizontal arrows) in peripheral nuclei throughout the region of the presumptive germ band. General transcriptional activators (open circles) and posterior-specific activators, possibly cad proteins (open triangles), are present as indicated. $(B)$ During cycle 14, ftz transcription is eliminated in nuclei of the presumptive odd-numbered parasegments by repressors, possibly $h$ and $e v e$ proteins (solid circles). (C) By the cellular blastoderm stage, $f t z$ proteins (stippled squares) are translated and, in conjunction with other factors (open squares), enhance $f t z$ transcription through the upstream promoter element in epidermal precursor cells of the even-numbered parasegments. It is not known whether these additional factors are also present in other cells. The dashed triangle indicates that the posterior-specific activators are present only in a subset of presumptive epidermal cells. 
critical recognition elements premature. One exception is the promoter region between -276 and $-239 \mathrm{bp}$, which contains repressor element $\mathrm{R} 2$ and only one DNase I footprint site (data not shown). A CGGATAA sequence is protected in this region and also in the regions containing repressor elements R3 and R4. Currently, experiments are under way to examine the significance of this heptamer sequence, to localize the other regulatory elements more precisely, and to determine the factors that regulate $f t z$ transcription through these sites.

Although the results presented in this paper do not identify specific trans-acting factors of $f t z$ transcription, they do provide further insights into the types of factors involved. Furthermore, they support conclusions concerning the role of certain other segmentation genes in regulating $\mathrm{ftz}$ expression drawn from previous studies. In particular, the majority of activators appear to be general transcription factors, which may activate a number of zygotically expressed Drosophila genes. The identities of these factors are unknown. The factor that recognizes the $\mathrm{A} 2$ activator element functions primarily in the posterior parasegments, and may be the product of the caudal (cad) gene. The cad protein contains a homeo domain and is expressed in a posterior-to-anterior gradient, (Mlodzik et al. 1985; Macdonald and Struhl 1986); in addition, mutations in cad drastically reduce the level of expression in the posterior $f t z$ stripes (Macdonald and Struhl 1986).

Repressors of $f t z$ transcription function in a pair-rule pattern, in nuclei and cells that comprise the odd-numbered parasegments throughout the embryo. This result supports the conclusions of previous studies that the product of the segmentation gene $h$ represses $f t z$ expression directly, and that this interaction occurs at the level of transcriptional control /Carroll and Scott 1986; Howard and Ingham 1986; Hiromi and Gehring 1987; Ish-Horowicz and Pinchin 1987; Carroll et al. 1988a). However, it is unlikely that the $h$ product is the only repressor of $f t z$ transcription because the $f t z$ zebra stripe expression pattern does resolve partially, albeit more slowly, in $h$ mutant embryos. A second possible repressor is the product of the pair-rule gene even-skipped (eve), which binds to the $f t z$ zebra-stripe promoter region in vitro at several sites upstream of $-185 \mathrm{bp}$ /data not shown). However, the effects of mutations in the eve gene on $\mathrm{ftz}$ expression are more complicated than are mutations in the $h$ gene (Carroll and Scott 1986; Frasch and Levine 1987).

Products of the gap segmentation genes have also been postulated to regulate the expression of later-acting, pair-rule genes (Carroll et al. 1988; Ingham 1988, and references therein). Indeed, studies on the expression of the $h$ gene indicate that factors expressed in patterns consistent with gap gene expression act through separate promoter elements to activate $h$ transcription (Howard et al. 1988). We find no evidence for similar interactions with the $f t z$ promoter, consistent with the interpretation that the effects of gap gene mutations on $\mathrm{ftz}$ expression are indirect (Ingham et al. 1986).

\section{Experimental procedures}

Isolation and synthesis of RNA

The $f t z$ DNA template was transcribed in vitro with nuclear extracts prepared from 0 - to 12 -hr embryos as follows: Dechorionated embryos were frozen in liquid nitrogen, ground with a mortar and pestle, and resuspended in buffer $\mathrm{E}[60 \mathrm{mM} \mathrm{KCl}, 15$ mM NaCl, 15 mM HEPES (pH 7.6), 1 mM EDTA, 8.5\% sucrose, $1 \mathrm{mM}$ DTT, $0.1 \mathrm{mM}$ PMSF, $100 \mu \mathrm{g} / \mathrm{ml}$ sodium bisulfite, $5 \mu \mathrm{g} / \mathrm{ml}$ soybean trypsin inhibitor, $250 \mu \mathrm{g} / \mathrm{ml}$ spermidine, $50 \mu \mathrm{g} / \mathrm{ml}$ spermine]. This and all further procedures were carried out at $4^{\circ} \mathrm{C}$. The solution was homogenized and passed through a Nitex filter, and the nuclei were pelleted by centrifugation for $10 \mathrm{~min}$ at $10,000 \mathrm{rpm}$ in a Beckman JA20 rotor. Nuclei were resuspended in buffer $\mathrm{A}$ [ $100 \mathrm{~mm} \mathrm{KCl}, 10 \mathrm{~mm}$ HEPES ( $\mathrm{pH}$ 7.6), $5 \mathrm{~mm}$ $\mathrm{MgCl}_{2}, 0.1 \mathrm{mM}$ EDTA]. Ammonium sulfate was then added to a final concentration of $250 \mathrm{mM}$, the mixture was rotated gently for $30 \mathrm{~min}$, and the precipitate was pelleted by centrifugation for $1 \mathrm{hr}$ at $100,000 \mathrm{~g}$. The supernatant was collected, and ammonium sulfate was added to a final concentration of $2.0 \mathrm{M}$. The solution was rotated $30 \mathrm{~min}$ and centrifuged for $15 \mathrm{~min}$ at $100,000 \mathrm{~g}$. The protein pellet was then resuspended in buffer $\mathrm{C}$ [10\% glycerol, $25 \mathrm{~mm}$ HEPES ( $\mathrm{pH} 7.6$ ), $50 \mathrm{mM} \mathrm{KCl}, 0.1 \mathrm{~mm}$ EDTA, $1 \mathrm{mM}$ DTT), dialyzed against buffer $\mathrm{C}$, and stored frozen at $-80^{\circ} \mathrm{C}$ until further use.

\section{Primer extension analysis}

The primer extension assays used a synthetic 20 -mer oligonucleotide homologous to the $f t z$ gene in a position originally estimated to be $100 \mathrm{bp}$ from the start point of transcription. The $5^{\prime}$ end of this probe coincides with a RsaI site in the genomic DNA. The primer was ${ }^{32} \mathrm{P}$-end-labeled using T4 polynucleotide kinase (U.S. Biochemical Corp.). Primer extension was performed according to Wiederrecht et al. (1987) with the following modifications: $10 \mu \mathrm{g}$ of poly(A) ${ }^{+}$RNA, isolated from 0 to 12-hr embryos (Maniatis et al. 1982) or one-fifth the RNA from an in vitro transcription reaction (Parker and Topol 1984) were used for each assay. RNA and primer were combined, heated at $65^{\circ} \mathrm{C}$ for $4 \mathrm{~min}$, and annealed at $52^{\circ} \mathrm{C}$ for $1 \mathrm{hr}$; the primer was extended using avian myeloblastosis virus (AMV) reverse transcriptase (Boehringer-Mannheim) at $37^{\circ} \mathrm{C}$ for 45 min. To obtain sequencing lanes, the appropriate $f t z$ genomic $R s a I$ fragment was similarly end-labeled and sequenced by the method of Maxam and Gilbert (1980). Both sequenced and extension products were electrophoresed on a $6 \%$ acrylamide, $8 \mathrm{M}$ urea gel and exposed to X-ray film overnight.

Construction of $\mathrm{ftz}-\mathrm{lacZ}$ fusions and P-element transformation

The source of the DNA for these experiments was a plasmid containing the ftz-lacA fusion gene of Hiromi et al. (1985), inserted between the SalI and EcoRI sites of pAT153. This construct contains $f t z$ DNA from -669 to $+73 \mathrm{bp}$ from the cap site (the zebra stripe promoter) ligated to the Escherichia coli $l a c Z$ gene within the second amino acid of the $f t z$-coding region. At the $3^{\prime}$ end of the lacZ gene is a Drosophila hsp 70 terminator, which includes a termination codon and polyadenylation signal. Deletions $\left\langle 5^{\prime}\right\rangle$ were generated by $X b a I$ restriction digestion of this plasmid $5^{\prime}$ of the $f t z$ promoter, followed by exonuclease III/mung bean nuclease treatment, according to the manufacturer's instructions (Stratagene Cloning Systems). HindIII linkers, $10 \mathrm{bp}$ in size (New England Biolabs), were added, and the deletion fragments were propagated in the Stratagene Bluescript $\mathrm{M13}$ + vector, and subsequently were subcloned into a Carnegie 20 vector. 
The $3^{\prime}$ deletions were generated by restriction digestion of the original plasmid with EcoRI, followed by the identical exonuclease III/mung bean digestion and HindIII linker attachment procedure. These deletion fragments were inserted immediately upstream of the $5^{\prime} \Delta-40$ fragment in the Stratagene vector, and these fusions were then subcloned into Carnegie 20. All deletion end points were sequenced by the method of Maxam and Gilbert (1980). The hsp70L $\Delta-36$ construct was generated by subcloning the -669 to -36 -bp fragment from $3^{\prime} \Delta-36$ into HZ50PL (Hiromi and Gehring 1987), which contains the basal promoter and untranslated leader of the $h s p 70$ gene ligated to the E. coli lacZ gene and Drosophila hsp 70 terminator. The $E \Delta-669$ and $E \Delta-40$ constructs were generated by cloning the appropriate $f t z-l a c Z$ fusion gene fragments into a Carnegie 20 vector containing the 2.7-kb KpnI-XbaI upstream element. Germ-line transformation was performed by standard proce-

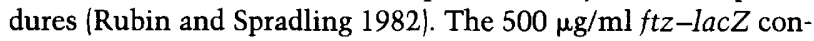
struct was coinjected with $100 \mu \mathrm{g} / \mathrm{ml}$ helper plasmid $\mathrm{pHS} \pi$ (Steller and Pirotta 1985) into ry ${ }^{506}$ embryos. All transformant lines were made homozygous or balanced over $F M 6, C y O$, or TM3 [these fly stocks are described in Lindsley and Grell (1968); $f t z^{9 H 34}$ is described in Jürgens et al. (1984)]. In only 2 of 207 individual transformant lines was more than one insertion observed.

\section{Detection and measurement of $\beta$-galactosidase activity}

Embryos examined individually by light microscopy were stained for $\beta$-galactosidase activity as follows. Dechorionated embryos were fixed with heptane saturated with $25 \%$ glutaraldehyde, $25 \mathrm{~mm}$ cacodylate buffer (pH 7.3), in depression slides for $10 \mathrm{~min}$ (Zalokar and Erk 1977). The embryos were rinsed in Ringer's solution, manually devitellinized, and stained for an appropriate length of time $(0.5-24 \mathrm{hr}$, depending on the activity of the $f t z-l a c Z$ construct) at $37^{\circ} \mathrm{C}$ in $30 \%$ Ficoll, $0.3 \% \mathrm{X}$-Gal, 5 $\mathrm{mM} \mathrm{K}_{4} \mathrm{Fe}(\mathrm{CN})_{6}, 5 \mathrm{mM} \mathrm{K}_{3} \mathrm{Fe}(\mathrm{CN})_{6}, 10 \mathrm{~mm}$ sodium phosphate $(\mathrm{pH}$ 7.2) (Raghavan et al. 1986). Ficoll inhibits the precipitation of $\mathrm{X}$-Gal during long incubation periods. Embryos were mounted in glycerol and photographed using Nomarski optics. Embryos were staged according to Campos-Ortega and Hartenstein (1985). $\beta$-Galactosidase expression was also examined in several transformant lines by antibody staining. Because this method of detection was less sensitive than the enzymatic assay using $\mathrm{X}$-Gal, it was not used to generate the results reported here.

For each transformant line, hundreds of individual embryos were examined. The staining pattern we describe for each construct represents the pattern found in most or all of the independent lines containing that construct. Of the 207 lines, 5 exhibited patterns different than all the others containing the same construct and are not included in this study. As has been reported by Hiromi et al. (1985), we found a fraction of the lines to exhibit ectopic staining in glial cells and in cells of the ventral nervous system (VNS) and observed $\beta$-galactosidase expression anterior to the cephalic furrow in all transformant lines. These staining patterns are not discussed here.

For the quantitative measurement of $\beta$-galactosidase activity, three to five homozygous viable and fertile lines were selected randomly for each construct. Embryos were collected at $25^{\circ} \mathrm{C}$ for $2.5 \mathrm{hr}$ and aged $3 \mathrm{hr}$ more. At this range of developmental stages, ectopic glial cell and neural precursor cell expression is not yet present. Embryos were dechorionated, homogenized in assay buffer $\left[50 \mathrm{~mm}\right.$ potassium phosphate, $1 \mathrm{mM} \mathrm{MgCl}_{2},(\mathrm{pH}$ $8.0)$, and centrifuged at $12,000 \mathrm{rpm}$ for $15 \mathrm{~min}$ at $4^{\circ} \mathrm{C}$. The supernatant was frozen at $-80^{\circ} \mathrm{C}$ until further use. For each transformant line tested, the total protein concentration in the supernatant was determined by Bio-Rad protein assay using
BSA as a standard. Extract containing $100 \mu \mathrm{g}$ of total protein was incubated with $5 \mathrm{~mm}$ chlorophenol red- $\beta$-D-galactopyranoside (CPRG, Boehringer-Mannheim) at $22^{\circ} \mathrm{C}$ for $2 \mathrm{hr}$, and the $\mathrm{OD}_{574}$ of the solution was determined spectrophotometrically (Simon and Lis 1987).

\section{Acknowledgments}

We are indebted to Yash Hiromi for providing plasmids and for helpful discussions throughout the course of this work. We thank Walter Gehring for encouragement and advice at the start of this project. We also thank Carol Mayeda for fly strains, Tim Hoey and Mike Levine for plasmids and bacterial strains, and Howard Lipshitz, Terry Strecker, Sue Celniker, and our colleagues in the Parker lab for comments on the manuscript. This work was supported by an National Institutes of Health (NIH) postdoctoral fellowship (GM11650) to C.R.D., an NIH predoctoral fellowship (T32 GM07616) to J.T., and a Markey Foundation grant to C.S.P. C.S.P. is a Rita Allen Foundation Scholar.

\section{References}

Akam, M. 1987. The molecular basis for metameric pattern in the Drosophila embryo. Development 101: 1-22.

Akam, M.E. and A. Martinez-Arias. 1985. The distribution of Ultrabithorax transcripts in Drosophila embryos. EMBO $\mathrm{F}$. 4: $1689-1700$.

Biggin, M.D. and R. Tjian. 1988. Transcriptional factors that activate the Ultrabithorax promoter in developmentally staged extracts. Cell 53: 699-711.

Campos-Ortega, J.A. and V. Hartenstein. 1985. The Embryonic development of Drosophila melanogaster. Springer-Verlag, Berlin.

Carroll, S.B. and M.P. Scott. 1985. Localization of the fushi tarazu protein during Drosophila embryogenesis. Cell 43: $47-57$.

1986. Zygotically active genes that affect the spatial expression of the fushi tarazu segmentation gene during early Drosophila embryogenesis. Cell 45: 113-126.

Carroll, S.B., G.M. Winslow, T. Schupbach, and M.P. Scott. 1986. Maternal control of Drosophila segmentation gene expression. Nature 323: 278-280.

Carroll, S.B., S. DiNardo, P. O'Farrell, R.A.H. White, and M.P. Scott. 1988a. Temporal and spatial relationships between segmentation and homeotic gene expression in Drosophila embryos: Distributions of the fushi tarazu, engrailed, Sex combs reduced, Antennapedia, and Ultrabithorax proteins. Genes Dev. 2: 350-360.

Carroll, S.B., A. Laughon, and B.S. Thalley. 1988b. Expression, function, and regulation of the hairy segmentation protein in the Drosophila embryo. Genes Dev. 2: 883-890.

Doe, C.Q., Y. Hiromi, W.J. Gehring, and C.S. Goodman. 1988. Expression and function of the segmentation gene fushi tarazu during Drosophila neurogenesis. Science 239: 170175.

Duncan, I. 1986. Control of Bithorax complex functions by the segmentation gene fushi tarazu of $D$. melanogaster. Cell 47: 297-309.

Edgar, B.A., G.M. Odell, and G. Schubiger. 1987. Cytoarchitecture and the patterning of fushi tarazu expression in the Drosophila blastoderm. Genes Dev. 1: 1226-1237.

Edgar, B.A., M.P. Weir, G. Schubiger, and T. Kornberg. 1986. Repression and turnover pattern fushi tarazu RNA in the early Drosophila embryo. Cell 47: 747-754.

Frasch, M. and M. Levine. 1987. Complementary patterns of 
even-skipped and fushi tarazu expression involve their differential regulation by a common set of segmentation genes in Drosophila. Genes Dev. 1: 981-995.

Goodburn, S., H. Burstein, and T. Maniatis. 1986. The human B-interferon gene enhancer is under negative control. Cell 45: $601-610$.

Hafen, E., A. Kuroiwa, and W.J. Gehring. 1984. Spatial distribution of transcripts from the segmentation gene fushi tarazu during Drosophila embryonic development. Cell 37: 833841.

Harding, K., C. Rushlow, H.J. Doyle, T. Hoey, and M. Levine. 1986. Cross-regulatory interactions among pair-rule genes in Drosophila. Science 233: 953-959.

Hiromi, Y. and W.J. Gehring. 1987. Regulation and function of the Drosophila segmentation gene fushi tarazu. Cell 50: $963-974$

Hiromi, Y., A. Kuroiwa, and W.J. Gehring. 1985. Control elements of the Drosophila segmentation gene fushi tarazu. Cell 43: 603-613.

Howard, K. and P. Ingham. 1986. Regulatory interactions between the segmentation genes fushi tarazu, hairy, and engrailed in the Drosophila blastoderm. Cell 44: 949-957.

Howard, K., P. Ingham, and C. Rushlow. 1988. Region-specific alleles of the Drosophila segmentation gene hairy. Genes Dev. 2: 1037-1046.

Hultmark, D., R. Klemenz, and W.J. Gehring. 1986. Translational and transcriptional control elements in the untranslated leader of the heat shock gene hsp22. Cell 44: 429-438.

Ingham, P. 1988. The molecular genetics of embryonic pattern formation in Drosophila. Nature 335: 25-34.

Ingham, P.W. and A. Martinez-Arias. 1986. The correct activation of Antennapedia and bithorax complex genes requires the fushi tarazu gene. Nature 324: 592-597.

Ingham, P.W., D. Ish-Horowicz, and K. Howard. 1986 Correlative changes in homeotic and segmentation gene expression in Krüppel mutant embryos of Drosophila. EMBO $J$. 5: 1659-1665.

Ish-Horowicz, D. and S.M. Pinchin. 1987. Pattern abnormalities induced by ectopic expression of the Drosophila gene hairy are associated with repression of $f t z$ transcription. Cell 51: 405-415.

Jürgens, G., E. Wieschaus, C. Nüsslein-Volhard, and $\mathrm{H}$. Kluding. 1984. Mutations affecting the pattern of the larval cuticle in Drosophila melanogaster. II. Zygotic loci on the third chromosome. Wilhelm Roux's Arch. Dev. Biol. 193: $283-295$.

Krause, H.M., R. Klemenz, and W.J. Gehring. 1988. Expression, modification, and localization of the fushi tarazu protein in Drosophila embryos. Genes Dev. 2: 1021-1036

Kuroiwa, A., E. Hafen, and W.J. Gehring. 1984. Cloning and transcriptional analysis of the segmentation gene fushi tarazu of Drosophila. Cell 37: 825-831.

Laughon, A. and M.P. Scott. 1984. Sequence of a Drosophila segmentation gene: Protein structure homology with DNAbinding proteins. Nature 310: 25-31.

Lawrence, P.A., P. Johnston, P. Macdonald, and G. Struhl. 1987. Borders of parasegments in Drosophila embryos are delimited by the fushi tarazu and even-skipped genes. Nature 328: $440-442$.

Lindsley, D.L. and E.H. Grell. 1968. Genetic Variations of Drosophila melanogaster. Carnegie Inst. Washington Publ. No. 627.

Macdonald, P.M. and G. Struhl. 1986. A molecular gradient in early Drosophila embryos and its role in specifying the body pattern. Nature 324: 537-545.

Maniatis, T., E.F. Fritsch, and J. Sambrook. 1982. Molecular cloning: A laboratory manual. Cold Spring Harbor Laboratory, Cold Spring Harbor, New York.

Martinez-Arias, A. and P.A. Lawrence. 1985. Parasegments and compartments in the Drosophila embryo. Nature 313: 639642.

Martinez-Arias, A., P.W. Ingham, M.P. Scott, and M.E. Akam. 1987. The spatial and temporal deployment of $D f d$ and $S c r$ transcripts throughout development of Drosophila. Devel opment 100: 673-683.

Maxam, A.M. and W. Gilbert. 1980. Sequencing end-labelled DNA with base-specific chemical cleavages. Methods En zymol. 65: 499-560.

Mitchell, P.J., C. Wang, and R. Tjian. 1987. Positive and negative regulation of transcription in vitro: Enhancer-binding protein AP-2 is inhibited by SV40 T antigen. Cell 50: 847861.

Mlodzik, M., A. Fjose, and W. Gehring. 1985. Isolation of caudal, a Drosophila homeo box-containing gene with maternal expression, whose transcripts form a concentration gradient at the pre-blastoderm stage. $E M B O$ I. 4: 29612969.

Nüsslein-Volhard, C., H.G. Frohnhofer, and R. Lehman. 1987. Determination of anteroposterior polarity in the Drosophila embryo. Science 238: 1675-1681.

Parker, C.S. and J. Topol. 1984. A Drosophila RNA polymerase II transcripton factor contains a promoter-region-specific DNA binding activity. Cell 36: 357-369.

Peck, L.J. and J.C. Wang. 1981. Sequence dependence of the helical repeat of DNA in solution. Nature 292: 375-378.

Raghavan, K.V., M.A. Crosby, P.H. Mathers, and E. Meyerowitz. 1986. Sequences sufficient for correct regulation of Sgs-3 lie close to or within the gene. EMBO J. 5: 3321-3326.

Rhodes, D. and A. Klug. 1981. Sequence dependent helical periodicity of DNA. Nature 292: 378-380.

Rubin, G.M. and A.C. Spradling. 1982. Genetic transformation of Drosophila with transposable element vectors. Science 218: 348-353.

Scott, M.P. and S.B. Carroll. 1987. The segmentation and homeotic gene network in early Drosophila development. Cell 51: $689-698$.

Simon, J.A. and J.T. Lis. 1987. A germline transformation analysis reveals flexibility in the organization of heat shock consensus elements. Nucleic Acids Res. 15: 2971-2984.

Sollner-Webb, B. and R.H. Reeder. 1979. The nucleotide sequence of the initiation and termination sites for ribosomal RNA transcription in X. laevis. Cell 18: 485-499.

Steller, H. and V. Pirotta. 1985. Expression of the Drosophila white gene under the control of the hsp 70 heat shock promoter. EMBO I. 4: 3765-3772.

Struhl, G. 1985. Near-reciprocal phenotypes caused by inactivation or indiscriminate expression of the Drosophila segmentation gene ftz. Nature 318: 677-680.

Topol, J., G. Wiederrecht, and C.S. Parker. 1987. Biochemical analysis of the fushi tarazu and Ultrabithorax promoter regions. In Genetic regulation of development, (ed. W.F. Loomis), pp. 3-12. Alan R. Liss, New York.

Wakimoto, B.T., F.B. Turner, and T.C. Kaufman. 1984. Defects in embryogenesis in mutants associated with the Antennapedia gene complex of Drosophila melanogaster. Dev. Biol. 102: $147-172$.

Weiner, A.J., M.P. Scott, and T.C. Kaufman. 1984. A molecular analysis of fushi tarazu, a gene in Drosophila melanogaster that encodes a product affecting embryonic segment number and cell fate. Cell 37: 843-851

Weir, M.P. and T. Kornberg. 1985. Patterns of engrailed and fushi tarazu transcripts reveal novel intermediate stages in 
Dearolf et al.

Drosophila segmentation. Nature 318: 433-439.

Wiederrecht, G., D.J. Shuey, W.A. Kibbe, and C.S. Parker. 1987. The Saccharomyces and Drosophila heat shock transcription factors are identical in size and DNA binding properties. Cell 48: $507-515$.

Zalokar, M. and I. Erk. 1977. Phase-partition fixation and staining of Drosophila eggs. Stain Technol. 52: 89-95. 


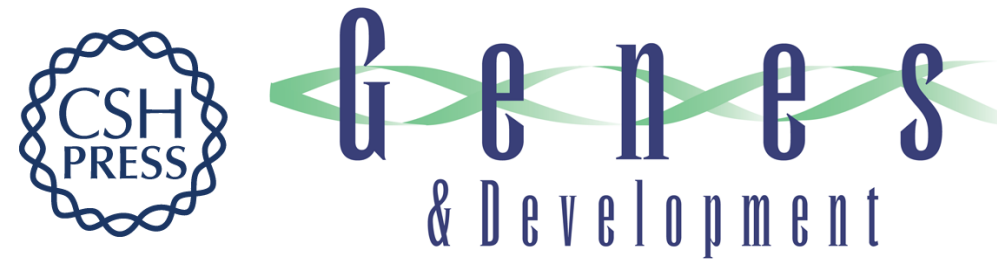

\section{Transcriptional control of Drosophila fushi tarazu zebra stripe expression.}

C R Dearolf, J Topol and C S Parker

Genes Dev. 1989, 3:

Access the most recent version at doi:10.1101/gad.3.3.384

References This article cites 52 articles, 12 of which can be accessed free at:

http://genesdev.cshlp.org/content/3/3/384.full.html\#ref-list-1

License

Email Alerting

Service

Receive free email alerts when new articles cite this article - sign up in the box at the top right corner of the article or click here.

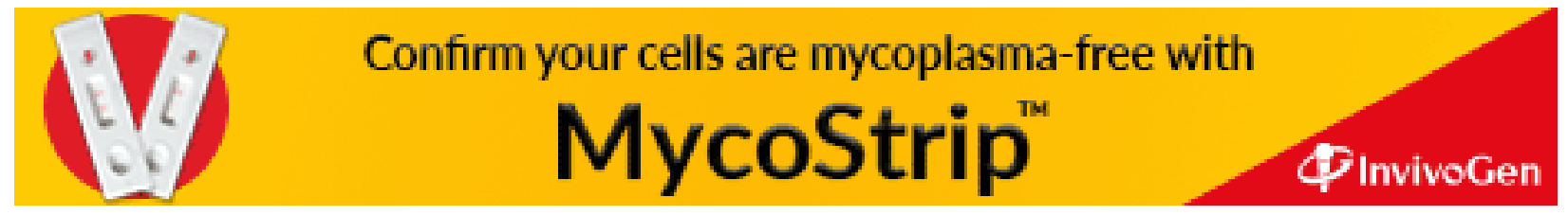

